\title{
RESEARCH OF THE PHYSICAL PROPERTIES OF DIESEL
}

\section{FUEL-HYDROGEN MIXTURES}

\section{L.I. Leybovych, B.V. Dymo, S.N. Anastasenko Y.V. Yevstigneyev}

Admiral Makarov National University of Shipbuilding, Heroes of Stalingrad Avenue, 9, Mykolaiv 54025, Ukraine

Email: recycle.lev@gmail.com

The change in the viscosity of diesel fuel with dissolved hydrogen, the rate of dissolution of hydrogen in the diesel fuel, and the hydrogen diffusion coefficient in diesel fuel were experimentally determined. Dissolving hydrogen in liquid fuel changes its physical-chemical properties. It has been found that the viscosity and density of diesel fuel change little when it is saturated with hydrogen. The flashpoint in a closed crucible is reduced by $3-4{ }^{\circ} \mathrm{C}$. The rate of dissolution of hydrogen in diesel fuel has been investigated. It has been found that the diffusion coefficient of hydrogen in diesel fuel depends significantly on the initial concentration of $\mathrm{H}_{2}$ in the fuel. The liquid fuel is advisable to supply with saturated hydrogen for the safety of the heat engine operation. The design of the hydrogen fuel saturation system with a special hydrogen sensor based on the MQ-8 sensor was proposed. The system of protection of the research stand from unauthorized emissions of hydrogen into the environment has been worked out. The protection ensures the shutdown of the stand equipment when the hydrogen concentration in the zone of its generation and supply to the fuel is at the level of $1 \%$.

Keywords. Hydrogen, diesel fuel, hydrogen dissolution, physical properties of a diesel fuel-hydrogen mixture.

INTRODUCTION. Hydrogen is one of the most prospective environmentally friendly sources of energy, thermal energy. Burning hydrogen or fuel-hydrogen mixtures (FHM) reduces emissions of carbon monoxide (CO), carbon hydride $(\mathrm{CH})$ and particulate matter. Wide limits of hydrogen flammability make it possible to organize high-quality control of the power of an internal combustion engine (ICE), as well as to increase the efficiency of an internal combustion engine at partial loads. When burning lean mixtures of hydrogen with air, it is possible to radically reduce emissions of nitrogen oxides (NOx) without significant material costs [1-3].

In this case, the concentration of hydrogen in the air in front of the cylinders of the internal combustion engine should be significantly less than $4 \%$ to avoid the risk of detonation in the cylinders of the internal combustion engine [5-6].

The reactionary effect of a small amount of hydrogen in the fuel-air mixture significantly 
affects the completeness of fuel combustion and the number of emissions of toxic substances $(\mathrm{CO}, \mathrm{NOx}$, etc.) $[7,8]$.

Carbon dioxide $\left(\mathrm{CO}_{2}\right)$ is a significant constituent of fuel gases. For example, in the exhaust gases of vehicles, the amount of $\mathrm{CO}_{2}$ varies from 22 to $43 \%$, depending on the composition of the fuel. It is possible to reduce carbon dioxide emissions by switching to hydrogen fuel or hydrogen-rich fuel. Emissions of $\mathrm{CO}_{2}$ and toxic gases (except NOx) can be practically reduced to zero [9].

An important aspect of using hydrogen as a fuel (or its additives to fuel) is the safety of equipment operation. Hydrogen-fueled equipment should be equipped with $\mathrm{H} 2$ detectors [10]. These detectors should give an alarm when the hydrogen concentration in the air is $1 \%$. This value is one-fourth of the lower flammability limit of hydrogen. The indicated value of the hydrogen concentration in the air in front of the cylinders of an internal combustion engine is rather difficult to ensure. It is easier to meet this requirement upon preliminary saturation of liquid fuel with hydrogen $[11,12]$. However, in any case, it is necessary to equip fuel enrichment systems with hydrogen and mobile $\mathrm{H}_{2}$ sensors operating in the concentration range of up to $1 \%$. The safety of the internal combustion engine depends on the physical properties of fuel-hydrogen mixtures. Also, the structural design of the system for the formation and supply of a fuel-hydrogen mixture to heat generating equipment largely depends on the physical properties of this mixture [13].

The inputting of hydrogen into the fuel changes the physical parameters of the latter. And when the physical parameters of the fuel change, the initial conditions for determining the ICE safety criteria change [14]. When hydrogen is added to the fuel such indicators as the velocity of flame-front propagation, the detonation conditions of the composite fuels; octane number [15] change also are changed. These indicators can be assessed based on data on the viscosity of fuel-hydrogen mixtures, the diffusion coefficient of hydrogen in fuel, etc.

Fuel viscosity significantly affects fuel atomization [16]. The dispersion of fuel droplets when atomized determines the kinetics of fuel combustion. The literature lacks data on the effect of dissolved hydrogen on the viscosity of fuel-hydrogen mixtures. In addition, the structural design of the fuel saturation system with hydrogen significantly depends on the rate of dissolution of $\mathrm{H}_{2}$ in the fuel. Analysis of the data $[17,18]$ has shown that the time to an equilibrium state in the liquid hydrogen fuel system could reach several hours. But the data $[17,18]$ are not sufficient to determine the kinetics of hydrogen solubility in fuel.

The aim of this work was the determination of:

- the change in the viscosity of diesel fuel when hydrogen dissolves in it;

- the rate of dissolution of hydrogen in diesel fuel;

- the hydrogen diffusion coefficient in diesel fuel.

EXPERIMENT AND DISCUSSION OF THE RESULTS. Materials. Diesel fuel accounts for more than $50 \%$ of all fuel consumed in the world. Diesel fuel combustion products are highly toxic $[7,8]$. Diesel and hydrogen mixtures are less toxic than pure diesel. Therefore, it is advisable to consider physical properties of a diesel fuel-hydrogen mixture as a factor in reducing the toxicity of combustion products. 
The solubility of hydrogen in liquid fuels depends on temperature and pressure during saturation [19-21]. From the standpoint of reliability, the process of fuel saturation with hydrogen is expedient to be carried out at atmospheric pressure. Therefore, experiments on the solubility of hydrogen in diesel fuel were carried out at atmospheric pressure in the temperature range from 25 to $50{ }^{\circ} \mathrm{C}$ according to the method described in scientific publications $[22,23]$. In experimental studies, diesel fuel was used with the following characteristics at $25^{\circ} \mathrm{C}$ : density $-845 \mathrm{~kg} / \mathrm{m}^{3}$; viscosity $-1 \mathrm{cSt}$; flashpoint in an open crucible $-91^{\circ} \mathrm{C}$; in a closed crucible $-69^{\circ} \mathrm{C}$.

The studies have been carried out on the experimental research stand (Fig. 1).

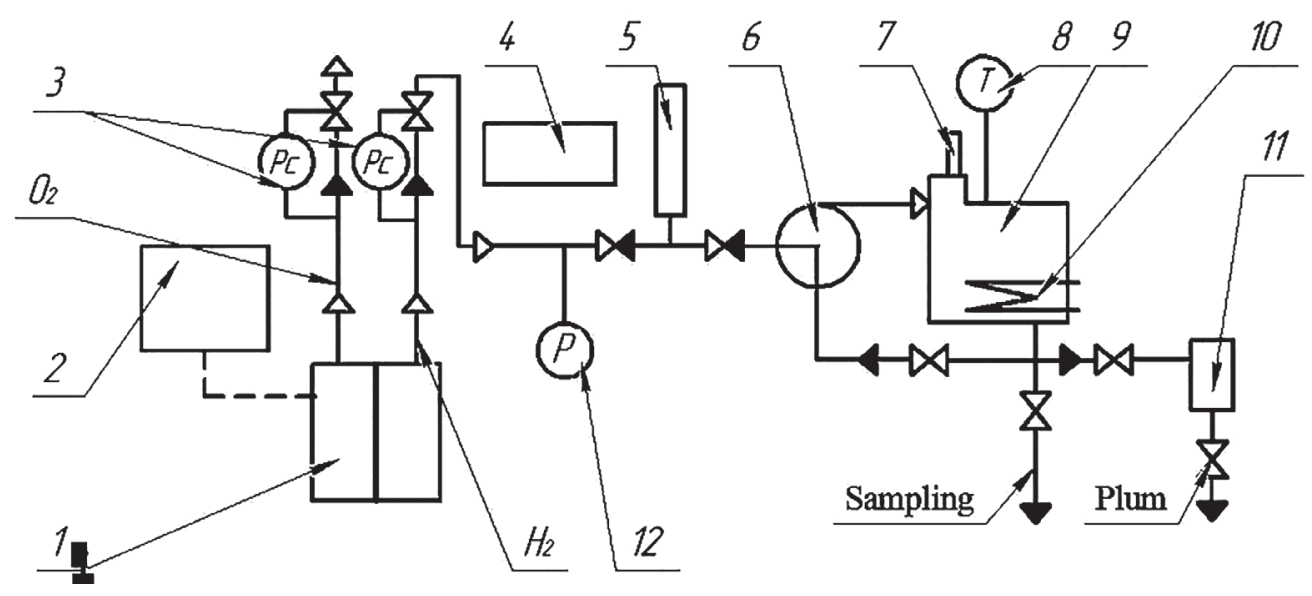

Fig. 1. Research stand.

1 - hydrogen generator; 2 - power supply; 3 - pressure regulator; 4 - hydrogen sensor;

5 - hydrogen dispenser; 6 - centrifugal pump; 7 - temperature sensor; 8 - the sensor of level of gaseous hydrogen in fuel tank; 9 - fuel tank; 10 - heater; 11 - viscometer; 12 - pressure sensor.

The operation principle of the stand. Fuel is poured into the fuel tank (9) so that there is no free air volume in it. The amount of fuel poured in is $1200 \pm 5 \mathrm{ml}$. The tank has a heater (10) and a viscometer (11) built-in to maintain the fuel temperature at a given level. The fuel circulates in the system using a centrifugal pump (6). Hydrogen is dosed to the system discretely by $10 \pm 0.1 \mathrm{ml}$ using a hydrogen dispenser (5). The completion of the process of fuel saturation with hydrogen was determined by the time of dissolution of the last dose in a volume of $10 \pm 0.1 \mathrm{ml}$ using a temperature sensor (7). The viscosity of the fuel is measured using a viscometer (11). The viscosity of diesel fuel and FHM based on diesel fuel was investigated on a Cannon-Fenske routine capillary viscometer with the following technical data: viscosity measurement range $-0.4 \ldots 2 \mathrm{cSt}$; nominal constant 0,002 .

The flash point of the fuel-hydrogen mixture was determined on a PE-TVO apparatus, the operation of which is based on the Brenken principle, and allows the measurement of the flash point in accordance with American standards ASTM D92. 
The safety system for hydrogen generation and dosing was tested simultaneously with studies of the physical properties of a diesel fuel-hydrogen mixture. Hydrogen leaks were monitored by an MQ-8 sensor connected to the Arduino NANO V3.0 CH340G platform designed based on the Atmega328P microcontroller. Such an assembly of the sensor and controller makes it possible to use it both in the stand safety system and in researching hydrogen desorption from the mixture. The general view of the control system is shown in Fig. 2.

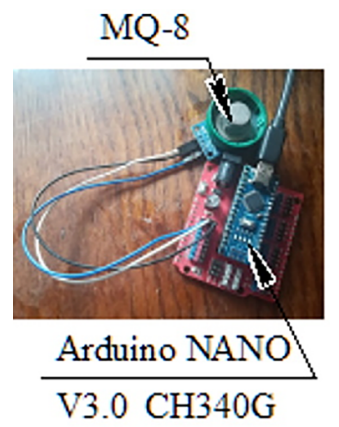

Fig. 2. $\mathrm{H}_{2}$ concentration control sensor.
The MQ-8 sensor together with Arduino NANO V3.0 CH340G was calibrated according to the standard EQASOP-FieldCalibrat method. The calibration results are shown in Fig. 3.

The regression dependence for assembling the MQ-8 sensor together with Arduino NANO microcontroller is as follows (1).

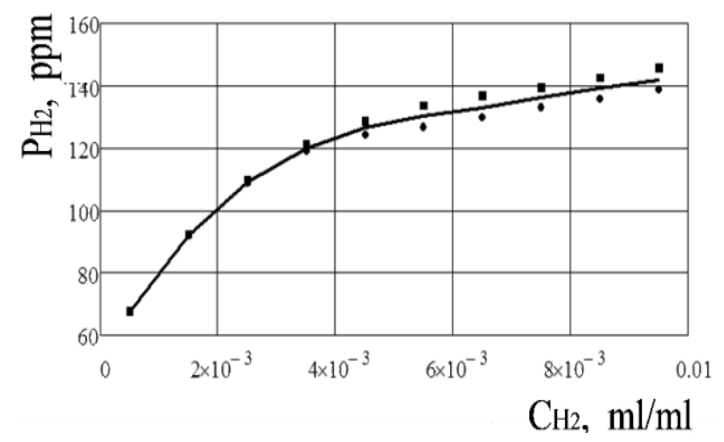

Fig 3. Calibration of the MQ-8 sensor in conjunction with Arduino NANO V3.0 CH340G.

$$
\begin{gathered}
a_{0}=51,546 ; a_{1}=3,409 \cdot 10^{4} ; a_{2}=-5,101 \cdot 10^{6} \\
a_{4}=113,595 ; \quad a_{5}=3,001 \cdot 10^{3} . \\
C_{v}=0,5 \cdot 10^{-3}, 1,5 \cdot 10^{-3} \ldots 10 \cdot 10^{-3} . \\
C_{p}\left(C_{v}\right)=\begin{array}{c}
a_{0}+a_{1} \cdot C_{v}+a_{2} \cdot C_{v}^{2}+a_{3} \cdot C_{v}^{3} \text { if } 0 \leq C_{v} \leq 5 \cdot 10^{-3} \\
a_{4}+a_{5} \cdot C_{v} \text { if } 5 \cdot 10^{-3} \leq C_{v} \leq 10 \cdot 10^{-3}
\end{array}
\end{gathered}
$$

$\mathrm{C}_{\mathrm{p}}$ - sensor readings, $\mathrm{ppm}, \mathrm{C}_{\mathrm{v}}$ - hydrogen concentration in the calibration vessel, $\mathrm{ml} / \mathrm{ml}$.

At hydrogen concentrations in the calibration container up to $3.5 \cdot 10^{-3} \mathrm{ppm}$, the error of the calibration curve does not exceed $0.37 \%$. With the increase in the hydrogen concentration in the calibration vessel, the error of the calibration curve increases to $3.5 \%$.
Density, viscosity, and flashpoint of a mixture of diesel fuel and hydrogen.

Experimental data on determining the viscosity of diesel fuel and a mixture based on diesel fuel and hydrogen in the temperature range $15 \div 95{ }^{\circ} \mathrm{C}$ are shown in Fig. 4 . 
The dissolution of hydrogen in diesel fuel leads to a slight increase in the viscosity of the fuel-hydrogen mixture.

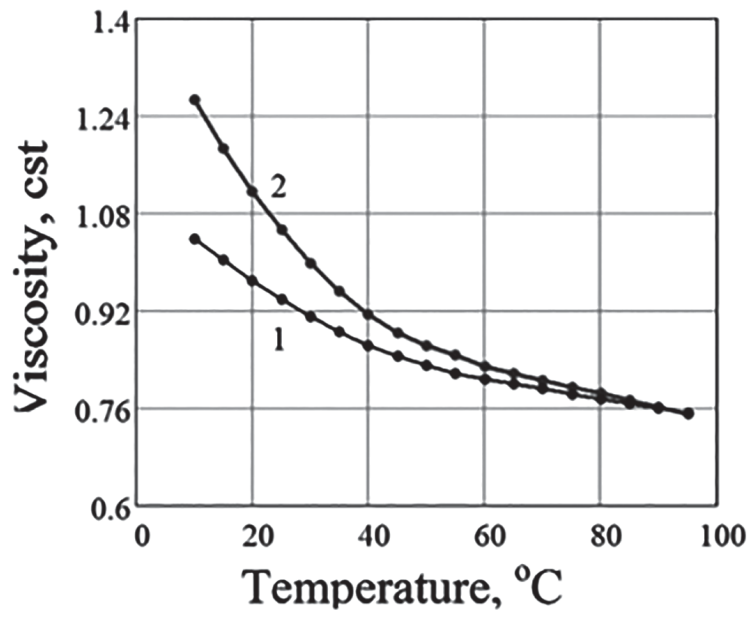

Fig. 4. Fuel viscosity versus temperature:

1- diesel fuel; 2 - fuel-hydrogen mixture $\left(\mathrm{H}_{2}\right.$ concentration $0.362 \mathrm{ml} / \mathrm{ml}$ ).

This dependence manifests itself at low temperatures to a greater extent than at high temperatures. The viscosity of hydrogen-saturated diesel fuel in the temperature range $15 \div 95{ }^{\circ} \mathrm{C}$ could be determined by the following regression dependence (2).

$$
\begin{aligned}
b_{0}=1,45 ; & b_{1}=-0,02 ; \quad b_{2}=1,648 \cdot 10^{-4} ; \\
b_{3}=0,96 ; & b_{4}=-2,2 \cdot 10^{-3} .
\end{aligned}
$$

$v \operatorname{vh}(T)=\mid \begin{gathered}b_{0}+b_{1} \cdot T+b_{2} \cdot T^{2} \text { if } 10 \leq T \leq 60 \\ b_{3}+b_{4} \cdot T \text { if } 60 \leq T \leq 95\end{gathered}$

$\mathrm{T}$ - the temperature of the fuel-hydrogen mixture, ${ }^{\circ} \mathrm{C}$; $v \mathrm{dh}(\mathrm{T})$ - the viscosity of hydrogen-saturated diesel fuel, cSt.

The increasing fuel viscosity is associated with the formation of weak bonds between fuel molecules and dissolved $\mathrm{H}_{2}$. At a hydrogen concentration in diesel fuel of $0.257 \mathrm{ml} / \mathrm{ml}$, the density of the fuel-hydrogen mixture was $\rho \mathrm{dh}=847 \mathrm{~kg} / \mathrm{m}^{3}$, with a temperature of $25^{\circ} \mathrm{C}$, which is in good agreement with the amount dissolved in the fuel. With the same hydrogen concentration in diesel fuel, the flashpoint decreased by an average of $3 \ldots 4^{\circ} \mathrm{C}$. However, it should be noted that in a closed crucible, at a temperature of about $60^{\circ} \mathrm{C}$, short-term flashes could appear periodically.

Dissolution rate of hydrogen in diesel fuel. The results of determining the rate of hydrogen dissolution in diesel fuel are shown in Fig. 5.

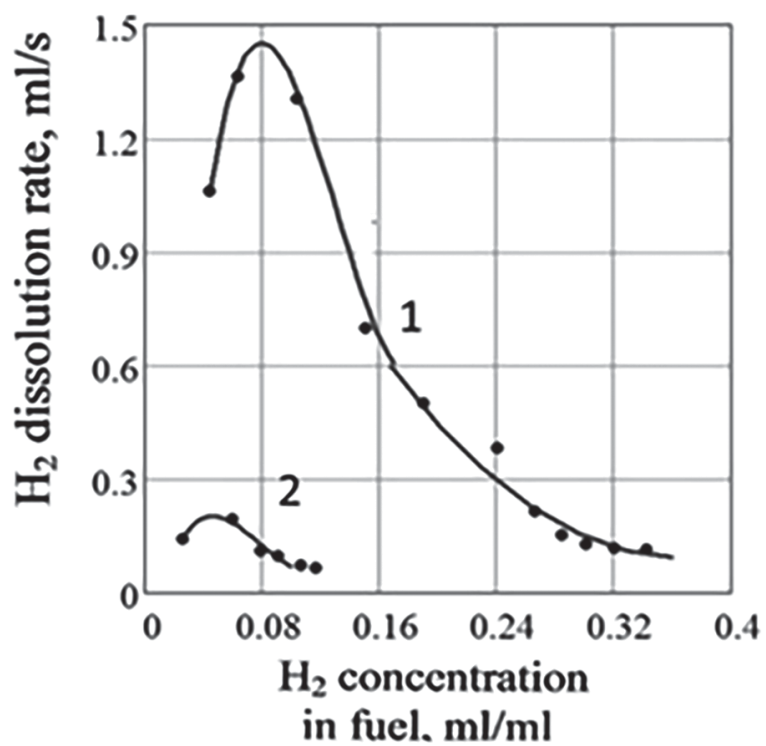

Fig. 5. The dependence of the rate of dissolution of hydrogen in diesel fuel on the concentration of hydrogen and the temperature of the $\mathrm{H}_{2}$ dissolution;

1 - temperature $28 \pm 1{ }^{\circ} \mathrm{C} ; 2-48 \pm 1{ }^{\circ} \mathrm{C}$.

The data analysis (Fig. 5.) has shown that: with an increase in temperature, the rate of dissolution of hydrogen in diesel fuel decreases; - the rate of dissolution of hydrogen in diesel fuel depends on the concentration of $\mathrm{H}_{2}$ in the 
fuel; - at a temperature of $28^{\circ} \mathrm{C}$, the maximum value of the dissolution rate is achieved at a hydrogen concentration in the fuel of $0.08 \mathrm{ml} / \mathrm{ml}$, - for a temperature of $48^{\circ} \mathrm{C}$, the maximum value of the hydrogen dissolution rate is achieved at a hydrogen concentration in the fuel of $0.06 \mathrm{ml} / \mathrm{ml}$.

Experimental studies have shown that preheating diesel fuel to a temperature of $50{ }^{\circ} \mathrm{C}$ and a subsequent decrease in the process temperature to $32{ }^{\circ} \mathrm{C}$ due to cooling leads to an in- crease in the rate of hydrogen dissolution. At a temperature of the process of dissolution of hydrogen in diesel fuel of $32^{\circ} \mathrm{C}$, the rate of dissolution of $\mathrm{H}_{2}$ is on average 1.25 times lower than for temperatures in the range $48-50^{\circ} \mathrm{C}$.

The rate of dissolution of hydrogen in diesel fuel, depending on the concentration of hydrogen in the fuel at temperatures of $25 \div 28{ }^{\circ} \mathrm{C}$ in the range of changes in the concentration of $\mathrm{H} 2$ from 0 to $0.36 \mathrm{ml} / \mathrm{ml}$ could be determined by the following regression dependence. (3.4).

$$
\begin{gathered}
V_{S}\left(C_{h}\right)=e_{0}+e_{1} \cdot C_{h}+e_{2} \cdot C_{h}^{2}+e_{3} \cdot C_{h}^{3} \text { if } 0.044 \leq C_{h} \leq 0.168 \\
V_{S}\left(C_{h}\right)=e_{4}+e_{5} \cdot C_{h} \quad \text { if } 0.168 \leq C_{h} \leq 0.36 \\
e_{0}=1,032 ; e_{1}=73,165 ; e_{2}=-662,0 ; \\
e_{3}=1,696 \cdot 10^{3} ; e_{4}=1,825 ; e_{5}=-9,5
\end{gathered}
$$

$C_{h}$ - the concentration of hydrogen in diesel fuel, $\mathrm{ml} / \mathrm{ml} ; V_{s}\left(C_{h}\right)$ - the dissolution rate, $\mathrm{ml} / \mathrm{s}$.

Diffusion of hydrogen in a FHM based on diesel fuel.

The diffusion coefficient of hydrogen in diesel fuel was determined by the method [25, 26 . The pressure of the medium in the container for the experiments was $753 \pm 1 \mathrm{~mm} \mathrm{Hg}$, the temperature was $25 \pm 1{ }^{\circ} \mathrm{C}$. The diffusion coefficient was determined as a functional dependence on the volume of the absorbed gas $V$, the gas concentration in the liquid $C_{h}$ of the determining size $l$, and the time $\tau$ of absorption of the volume by the liquid $D h=f(V, C h, l, \tau)$

Moreover, the diffusion coefficient is inversely proportional to the value of the gas concentration in the liquid. That is, with an increase in the saturation of the liquid with gas, the diffusion coefficient decreases.

The change in the hydrogen concentration in diesel fuel during the study of the diffusion process is shown in Fig. 6.

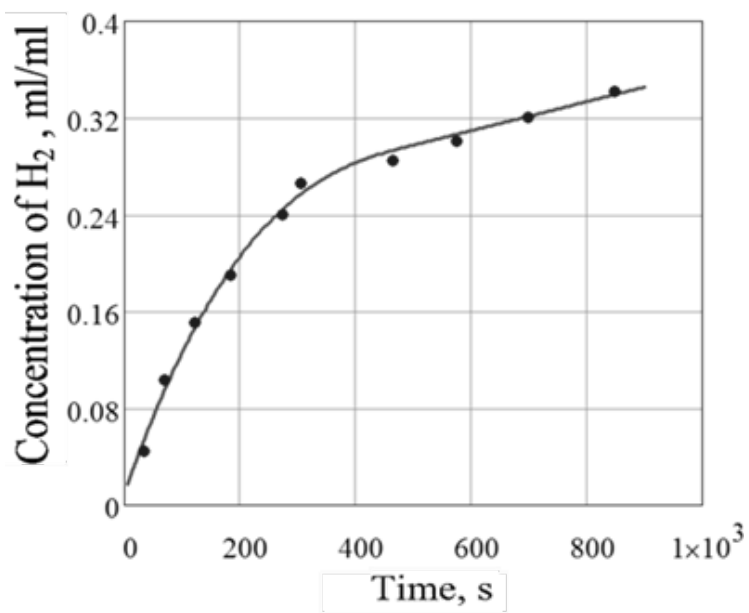

Fig. 6 Rate of change in hydrogen concentration in diesel fuel:

- average value; - experimental data. 
The fuel of the container was intensively mixed in the period of time.

The time interval between hydrogen supply to the fuel was $120 \pm 1 \mathrm{~s}$. A pump was used to average the current value of the hydrogen concentration in the fuel between the injections of hydrogen.

The diffusion coefficient of hydrogen in diesel fuel was determined from the time of solubility of $10 \pm 0.1 \mathrm{ml}$ of hydrogen. The completion of the process of hydrogen solu- bility in diesel fuel was recorded according to the data of temperature sensor (7), installed in a tank with fuel, into which $\mathrm{H}_{2}$ was dosed (Fig. 1). The accuracy of measuring the time of hydrogen dissolution was $\pm 3 \mathrm{~s}$. The supply of $\mathrm{H}_{2}$ into the tank with fuel was carried out discretely.

The change in the hydrogen concentration over time in diesel fuel at temperatures of $25 \pm 1{ }^{\circ} \mathrm{C}$, could be determined from the following regression dependence $(5,6)$.

$$
\begin{gathered}
C_{h}(\tau)=g_{0}+g_{1} \cdot \tau+g_{2} \cdot \tau^{2}+g_{3} \cdot \tau^{3} \quad \text { if } \quad 5 \leq \tau \leq 450 ; \\
C_{h}(\tau)=g_{4}+g_{5} \cdot \tau \quad \text { if } 450 \leq \tau \leq 900 ; \\
g_{0}=9,985 \cdot 10^{-3} ; g_{1}=1,371 \cdot 10^{-3} ; g_{2}=-2.241 \cdot 10^{-6} ; \\
g_{3}=1.281 \cdot 10^{-9} ; g_{4}=0,2375 ; g_{5}=1.2 \cdot 10^{-4} .
\end{gathered}
$$

$\mathrm{C}_{\mathrm{h}}(\tau)$ - the hydrogen concentration in diesel fuel, $\mathrm{ml} / \mathrm{ml} ; \tau$ - time, $\mathrm{s}$

The value of the diffusion coefficient of hydrogen in diesel fuel, calculated from the rate of hydrogen dissolution, is shown in Fig. 7.

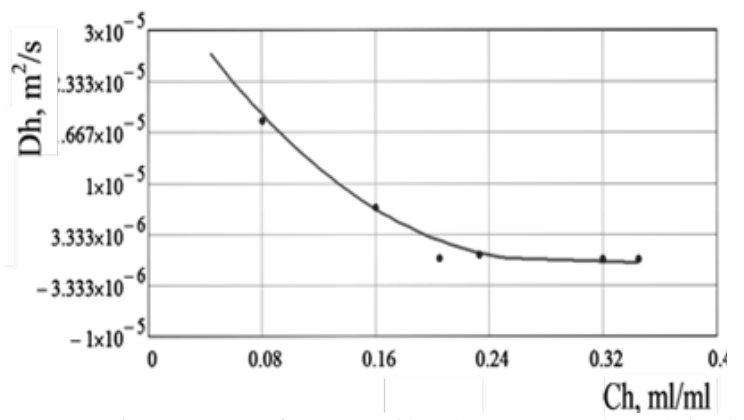

The data in Fig. 7 show that with an increase in the saturation of diesel fuel with hydrogen, the diffusion coefficient decreases. At the beginning of the hydrogen dissolution in fuel, the diffusion coefficient $D_{h}=(2,7 \ldots 3,0) \times 10^{-5} . \mathrm{m}^{2} / \mathrm{s}$. When the state of saturation of diesel fuel with hydrogen is reached, the diffusion coefficient decreases to $D h=1 \times 10^{-9} \mathrm{~m}^{2} / \mathrm{s}$.

The diffusion coefficient of hydrogen in diesel fuel $D_{h}$ at a temperature of $25 \pm 1^{\circ} \mathrm{C}$ could be determined from the following regression equation (7.8).

Fig. 7. Diffusion coefficient of hydrogen in diesel fuel.

$$
\begin{gathered}
D h(C h)=k 0+k 1 \cdot C h+k 2 \cdot C h^{2}+k 3 \cdot C h^{3} \text { if } 0.01 \leq C h \leq 0.25 ; \\
C h(\tau)=k 4+k 5 \cdot C h \quad \text { if } 0.25 \leq C h \leq 0,4 ; \\
k 0=3,85 \cdot 10^{-5} ; k 1=1,7 \cdot 10^{-6} ; ; k 2=6,124 \cdot 10^{-4} ; \\
k 3=2,36 \cdot 10^{-4} ; k 4=0,2375 ; k 5=-4,0 \cdot 10^{-6} .
\end{gathered}
$$

$\mathrm{Ch}$ - the hydrogen concentration in diesel fuel, $\mathrm{ml} / \mathrm{ml}$. 
CONCLUSION. Experimental studies of the physical properties of a mixture of diesel fuel with hydrogen have shown that at atmospheric pressure and a temperature of $25-30{ }^{\circ} \mathrm{C}$, the saturation concentration of hydrogen in diesel fuel does not exceed $0.4 \mathrm{ml} / \mathrm{ml}$. When the temperature rises during the dissolution of hydrogen in diesel fuel over $30^{\circ} \mathrm{C}$, the solubility of hydrogen deteriorates. The physical properties (density and viscosity) of hydrogenated diesel fuel change little. The flashpoint is reduced by 3 ... $4{ }^{\circ} \mathrm{C}$.

The rate of dissolution of hydrogen significantly depends on the concentration of hydrogen in the fuel. In the saturated state, the diffusion coefficients of hydrogen in diesel fuel are close to $\mathrm{Dh}=1 \times 10^{-9} \mathrm{~m}^{2} / \mathrm{s}$. The amount of hydrogen dissolved in diesel fuel does not form explosive concentrations when hydrogen is desorbed from the fuel.

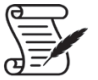

AKNOLEDGEMENT. The authors of the article are grateful to the enterprise Ltd «Teodora» for support in conducting experiments.

ДОСЛДЖЕННЯ ФІЗИЧНИХ ВЛАСТИВОСТЕЙ СУМШЕЙ ДИЗЕЛЬНЕ ПАЛИВО - ВОДЕНЬ

Л. І. Лейбович., Б. В. Димо, С. Н. Анастосенко, Ю. В. Євстегнєєв

Національний університет кораблебудування імені Адмірала Макарова, просп. Героїв Сталінграду, 9, Миколаїв 4025, Україна

E-mail: recycle.lev@gmail.com
Використання паливно-водневих сумішей в теплових машинах покращує процеси горіння палива. Також знижуються викиди в атмосферу токсичних продуктів із димовими газами. 3 огляду на безпечну роботу теплової машини доцільним $є$ подавання в неї рідкого палива, насиченого воднем. Це зумовлено тим, що коефіцієнт дифузії водню в рідинах значно нижчий, ніж у газах. У цьому випадку ймовірність утворення вибухонебезпечних концентрацій водню в повітрі значно менша, ніж при подаванні повітряно-водневих сумішей. Розчинення водню в рідкому паливі змінює його фізичні властивості. В літературі недостатньо даних щодо впливу розчиненого водню на в'язкість паливно-водневих сумішей. Крім цього, конструктивне виконання системи насичення палива воднем істотно залежить від швидкості розчинення $\mathrm{H}_{2}$ в паливі. Метою цієї роботи було експериментальне визначення зміни в'язкості дизельного палива при розчиненні в ньому водню; швидкості розчинення водню в дизельному паливі, коефіцієнта дифузії водню в дизельному паливі. Розроблено спеціальний стенд для дослідження процесів розчинення водню в рідкому паливі. Стенд обладнано спеціальним сенсором водню на основі датчика «MQ-8», що убезпечує виконання експериментального дослідження. У результаті експериментальних досліджень встановлено, що в'язкість і щільність дизельного палива мало змінюється при насиченні його воднем. Температура спалаху в закритому тиглі знижується на $3 \ldots 4{ }^{\circ} \mathrm{C}$. Досліджено швидкість розчинення водню в дизельному паливі. Встановлено, що коефіцієнт дифузії водню в дизельному паливі істотно залежить від початкової концентрації $H_{2}$ 
в паливі. Відпрацьовано систему захисту дослідного стенду від несанкціонованих викидів водню в навколишнє середовище. Захист забезпечує відключення обладнання стенду при концентрації водню в зоні його генерування і подавання в паливо на рівні $1 \%$.

Ключові слова: водень, дизельне паливо, розчинення водню, фізичні властивості суміші дизельне паливо - водень.

\section{REFERENCES}

1. Verhelst S. A study of the combustion in hydrogen-fuelled internal combustion engines. Department of Flow, Heat and Combustion Mechanics, Ghent University. 2005. 222.

2. Kim J. M., Kim Y. T., Lee J.T., Lee S. Y. Performance characteristics of hydrogen fueled engine with the direct injection and spark ignition system. SAE Technical Paper No. 95249. 1995. 11.

3. Ma J. Su, Y. Zhou, Y. \& Zhang Z. S imulation and prediction on the performance of a vehicle's hydrogen engine. Int. J. Hydrogen Energy. 2003.3 (28): 77-83.

4. Apostolescu N., Chiriac R. A. Study of Combustion of Hydrogen-Enriched Gasoline in a Spark Ignition Engine. SAE Technical Pape No. 960603. 1996. 14.

5. Coward H. F., Jones, G. W. Limits of flammability of gases and vapors. Bureau of Mines Bulletin No 503. 1952. 168.

6. Okumura T., Furuno S., Kim K. Effects of Hydrogen Addition to SI Engine on Knock Behavior. SAE Technical Paper.

No. 2004-01-1851. 2004. 13.

7. Fulton J., Lynch F., Willson B. Hydrogen for Cold Starting and Catalyst Heating in a
Methanol Vehicle.

SAE Technical Paper. No. 951956. 1995. 14.

https://doi.org/10.4271/951956

8. Zhou J. H., Cheung C. S., Leung C. W. Combustion, performance and emissions of a diesel engine with $\mathrm{H}_{2}, \mathrm{CH}_{4}$ and $\mathrm{H}_{2}-\mathrm{CH}_{4}$ addition. International Journal of Hydrogen Energy. 2014. 39(9): 4611-4621.

9. Nugroho Agung Pambudia, Kenshi Itaokaa, Atsushi Kurosawab, Natsuki Yama. Impact of hydrogen fuel for $\mathrm{CO}_{2}$ emission reduction in power generation sector in Japan. Energy Procedia, May 2017. 105: 3075-3082.

10. Cadwallader L. C., Herring J. S. Safety Issues with Hydrogen as a Vehicle Fuel. INEEL/ EXT-99-00522. 1999. 78. https://inldigitallibrary.inl.gov/sites/sti/sti/3318091.pdf/

11. Ubong E. U. Safety issues in hydrogen transportation. In Electrical Insulation Conference and Electrical Manufacturing samp; Coil Winding Technology Conference. 2003. 395401.

12. Parashuram R. Chitragar, Shivaprasad K. V., Kumar G. N. Use of Hydrogen in Internal Combustion Engines: A Comprehensive Study. Journal of Mechanical Engineering and Biomechanics. 2016. 1 (3): 84-96.

13. Alcock J. L., Shirvill L. C. \& Cracknell, R. F. Compilation of existing safety data on hydrogen and comparative fuels. Deliverable. Report EIHP2. 2001. 15.

14. Rivkin C., Burgess R., \& Buttner W. Hydrogen Technologies Safety Guide. National Renewable Energy Laboratory. Technical Report NREL/TP-5400-60948. 2015. 73.

15. Ceper B. A. Use of Hydrogen-Methane Blends in Internal Combustion Engines. $\mathrm{Hy}$ drogen Energy - Challenges and Perspectives, Dragica Minic, IntechOpen. 2012.

16. Krause P., Labuda R. The influence of liquid viscosity on atomized fuel mean droplet size determined by the laser diffraction method. New Trends in Production Engineering NTPE. 2018. 1 (1): 435-441. 
17. Luhring P., Schumpe A. Gas solubilities $\left(\mathrm{H}_{2}\right.$, $\mathrm{He}, \mathrm{N}_{2}, \mathrm{CO}, \mathrm{O}_{2}, \mathrm{Ar}, \mathrm{CO}_{2}$ ) in organic liquids at 293,2 K. Journal of Chemical Engineering Data 1989. 34 (2): 250-252.

18. Herskowitz M., Wisniak J., Skladman L. Hydrogen Solubility in Organic Liquids. J. Chem. Eng. 2016. 61(1): 19-34.

19. Ronzea D., Fongarlandb P., Pitaultb I., Forissierb M. Hydrogen solubility in straight run gasoil. Chemical Engineering Science. 2002. 57: 547-553.

20. Diesel and Gasoline Engine Exhausts and Sorne Nitroarenes International Agency for Research on Cancer. 2014. 46: 467.

21. Roger Torres, Jean-Charles, De Hemptinne, Machin I. (Improving the Modeling of Hydrogen Solubility in Heavy Oil Cuts Using an Augmented Grayson Streed (AGS) Approach. Oil Gas Science and Technology - Revue d'IFP Energies nouvelles, Institut Français du Pétrole. 2013. 68(2): 217-233.
22. Leybovych L. I., Yevstigneyev Y.V. Solubility of hydrogen in mixtures of liquid fuels at atmospheric pressure International periodic scientific journal "Modern engineering and innovative technologies". 2018. 5 (3): 46-50 (In Russian).

23. Leybovych L. I., Yevstigneyev Y.V. Regression equations for calculating the solubility of hydrogen in liquid fuels. Украӥнськиц хімічний журнал. 2019. 85 (12): 110-116.

24. Angelil R., Diemand J., Tanaka K. K., Tanaka H. Properties of liquid clusters in large-scale molecular dynamics nucleation simulations. J. Chem. Phys. 2014. 140(7): 074303.

25. Himmelblau D.M. Diffusion of dissolved gases in liquids. Chem. rev. 1964. 64 (5): 527-550.

26. Malik V.K., Hayduk W. A study-state capillary cell method for measuring gas-liquid diffusion coefficients. Can. J. Chem. Eng. 1968. 46: 462-466.

Стаття надійшла 17.10.2021. 